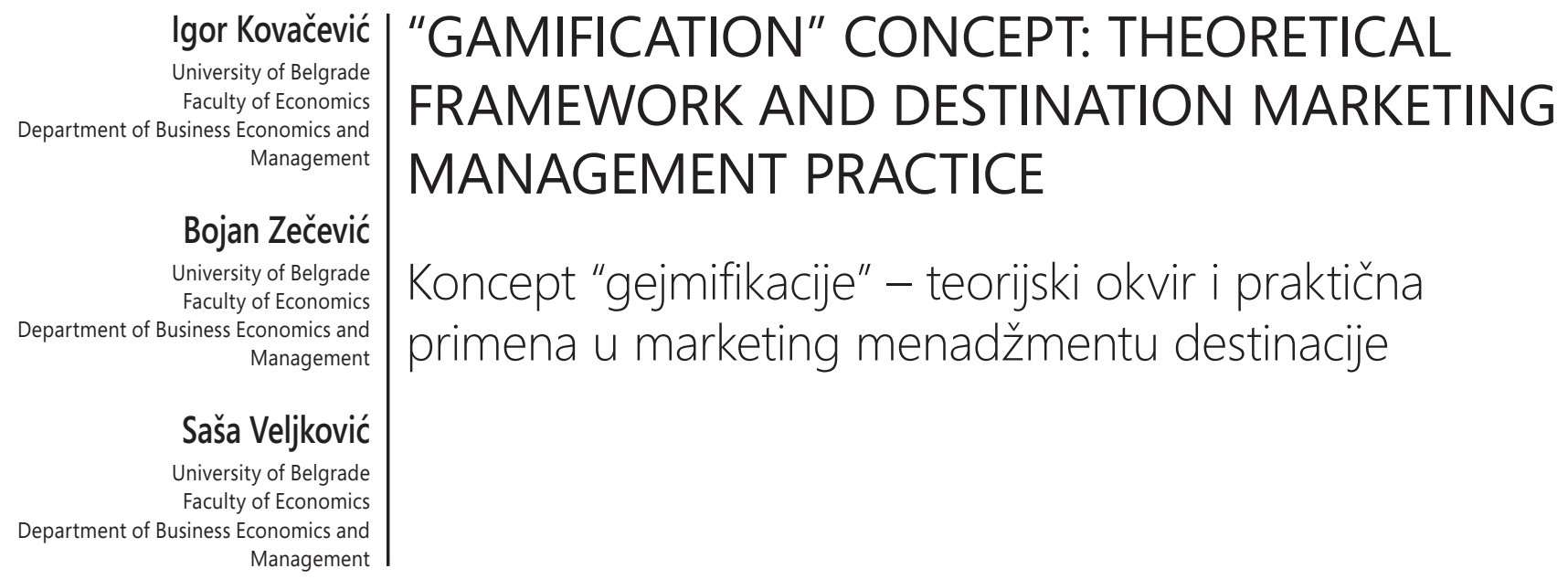

\begin{abstract}
The concept of gamification originated from the digital media industry, but found its application in the field of destination management as well. Although appeared six years ago, the concept has been the subject of a limited number of research studies, but none of them in the field of destination marketing and management, which makes this paper one of the pioneering works. As regards the implementation of gamification, it is critical to understand the framework, key elements, main techniques, and to be creative in customizing it to suit the requirements of a specific industry. It is necessary to distinguish gamification from the act of playing that has unstructured nature, as well as from the game that is created for fun and entertainment. Gamification is a marketing instrument used for developing client relationships, taking place in non-typical (nongame) and dynamical game environment. Analyzed case study reveals how the theoretical aspects are being implemented in real situations, creating important effects.
\end{abstract}

Key words: gamification, destination management, destination marketing, game, game elements

\begin{abstract}
Sažetak
lako je koncept gejmifikacije potekao iz sfere digitalnih medija, svoju primenu je našao i u oblasti menadžmenta destinacija. Ovaj koncept, iako se prvi put pojavio pre šest godina, privukao je pažnju ograničenog broja autora, ali nijednog iz oblasti destinacijskog marketinga i menadžmenta, što ovaj rad svrstava u kategoriju pionirskih. Suštinski bitno za implementaciju gejmifikacije je razumeti osnove, ključne elemente, glavne tehnike, kao i biti kreativan u prilagođavanju koncepta uslovima konkretne industrije. Gejmifikaciju je neophodno razlikovati od samog čina igranja igre, kojaje u prirodi nestrukturirana i kreirana za zabavu i razonodu. Gejmifikacija je marketing alat koji se koristi za razvoj odnosa sa potrošačima u okviru netipičnog i dinamičkog okruženja same igre. Analizirana studija slučaja pokazuje na koji način se teorijski utvrdeni principi implementiraju u praksi u realnim situacijama.
\end{abstract}

Ključne reči: gejmifikacija, destinacijski menadžment, destinacijski marketing, igra, elementi igre 


\section{Introduction to "gamification"}

Tourism represents one of the fastest growing industries in the world today and, despite the world economic crisis, its constant market growth is evident. Last year it was recorded over one billion international tourists. At the same time, when the total commercialization of ICT is present, tourism supply stakeholders are using internet based solutions and tools to anticipate, influence and satisfy the needs and wants of modern tourists. These changes are affecting all aspects of management and marketing and equally all destination stakeholders, from destination management organizations, via hotels and conference centers, to destination management companies, air carriers, and all other direct and indirect providers of tourism experience. The new, modern paradigm of tourism is shifting focus on the experience that tourists are having in a destination. The most successful are those service (experience) providers that are using technology to provide everlasting and unique experiences. Besides the development of online travel agencies, computerized reservation systems, dominance of social media and mobile phones in process of customer relationship management, the gamification concept is becoming more and more important.

Gamification is one of the most important technology trends and challenges that are common for all fields of marketing, and consumer/client communication, and according to predictions over $70 \%$ of world biggest companies will have at least one gamified application [8]. Therefore, the paper explains theoretical framework and base of the gamification concept, and analyzes the practical application in the field of tourist destination management, based on the Serbia Convention Bureau case study analysis.

\section{Defining the term "gamification"}

The term itself comes from the digital media industry, and that is the reason why terminology and certain words and phrases in the other fields can make this concept hard to understand and difficult to implement outside the digital media industry, including tourism as well. Authors of the paper, with all due respect to the essence and meaning of original terms, custom-fit the gamification concept to the needs of tourism management, and where the customization is not possible the original wording has been used.

The term "gamification" was used for the first time in 2008, but its wider usage started two years later. Authors of academic research papers on one side, and professional industry reports on the other side, agree on the general definition of gamification as "the integration of gaming dynamics in non-gaming environments" [21, p. 6]. In addition, papers of other authors define "gamification as the use of game design elements in non-game contexts" [6, p. 2]. It is possible to conclude that both definitions are using a wide approach, without enough inputs for the people that are facing the gamification for the first time, making it hard to implement in the field of destination management and marketing without prior customization. Also, the term "non-gaming" is not enough clear, so the paper suggests to use alternate term "non-typical environment" in order to make definition more understandable and applicable. Terms like game design and game elements will be analyzed later in the paper.

Further, the gamification concept is different from standard video games. Video games are explicitly designed for entertainment, with content that motivates users to remain engaged in an activity with unparalleled intensity and duration. Thus, game design is the term and approach for making different, non-game product, service, or application [6, p. 2]. Therefore, we can conclude that there are several basic elements of gamification [10, p. 23]: the game, the element, the non-game context and the design. The "game" is characterized by rules, competition and strife towards specified, discrete results by human participants. The "element" represents some basic characteristics of a concrete game. The "non-game context" considers that gamification uses game to satisfy other needs than just entertainment. The "design" is used to describe process of game creation and programing. There are several design levels, like interface design, pattern design, principles design and conceptual design [6, p. 3]. Interface design patterns such as badges, levels, or leaderboards make users change their behavior [5, p.121]. The game design needs to influence the user feedback and motivate them to keep playing. 
Based on the previous, we conclude that gamification represents a tool for engaging users in problem solving by motivating them and influencing their behavior. A properly designed game makes user totally focused on interacting with the game, abstracting all other factors outside the game. By using gamification as a tool in the process of business management, the situation will be created where targeted user will pay no attention to competitors and their messages as long as he has the opportunity to play and interact with properly designed game.

According to Kleinberg [11] "gamification is the application of gaming concepts to non-game experiences in order to drive desired behavior from an audience". Successful destinations are focused on providing tourists and guests with extraordinary experiences, and therefore we can suggest using gamification to achieve emotional connection and reaction of tourists/users. Probably the most important reason for companies to engage in gamification is its wished-for effect on players' perception of and engagement with the brand, and level of loyalty [21, p. 8]. Gamification is focused on encouraging engagement, motivation, brand awareness and loyalty among players [21, p. 7], [13, p. 16]. A very important aspect of gamification is education - to provide more knowledge on products, service and destination. However, destination management organizations always need to bear in mind the reason why users are engaging in the game.

It is necessary to distinguish gamification from the act of playing that has unstructured nature and from the game that is created for fun and entertainment [6, p. 3]. Modern communication systems, based on internet and other digital communication solutions, make gamification also internet-based, with interactivity and user-generated content as main characteristics.

Buhalis [3] points out that mobile technology is enriching tourist experiences by providing additional platform for gamification. Therefore, we can conclude that mobile technology is another tool for client relationship management. Further, the needs of modern tourists are different from traditional tourists, and therefore traditional tangible attractions (sea, sun, sand, and mountain) are changed for experiences. Tourists are looking for experiences, and various applications of gamification concepts (including the mobile technology platforms) make tourist experience destination in different ways. So, destinations providers will be successful as long as they are using new, different tools, such as gamification, in managing tourist experience.

Gamification concepts make users follow strict structure and behave in correlation with pre-defined rules, so they can respond to different levels of tasks and challenges. Following strict sequences and the hierarchy, users will accomplish final goal. Users are also led by the ambition to collect virtual points, like badges, pins and similar. Antin and Churchill [2, pp. 2-3] argue that virtual points in social media have five psychological functions: define the aim, provide instructions, earn reputation, retain status/ affirmation, and identification with a belonging group. It is also important to monitor the return on investment (ROI) resulting from the gamification. ROI can be measured as an increase in consumer interaction, engagement and loyalty, but also through the lead generation and sales volume increase.

\section{Techniques and elements of gamification}

The needs of game users or, more precisely, of the markets which are targeted by gamification can be divided into internal and external. Needs for scoring virtual, but also real awards, as well as needs for earning social reputation, are externally caused. On the other hand, internal are needs for upgrading the game skills.

Gamification can persuade users to change their behavior, using the following techniques [12, p. 3]:

- Reduction: simplifying the complex task in order to convince users to perform the task; if the users believe that by accomplishing that task he will benefit, it is more likely he will play it.

- Tunneling: game direction is pre-defined and guides users using the step-by-step principle; this technique keeps users from losing interest.

- Tailoring: providing all necessary information needed for successful completion of tasks.

- Suggestion: providing users with suggestions at the right time will increase their efficiency; if the suggestion is not relevant, it will not be acknowledged 
by user; creating a decision point at the time when it's appropriate to act is the fundamental point for success.

- Self-monitoring: to provide a feedback so the users can change own behavior.

- Conditioning: rewards make user come back and be more satisfied.

Some of the key game elements are [15, p. 145]

- Voluntarism: users choose whether they want to engage or not.

- Inefficiency: the essence of the game is to follow rules, and not to reach the best score in the best possible way.

- Limitations: conditions and environments are given and cannot be changed.

- Safety: game is the safe way to experience real situations (and destinations) in virtual context.

- Interaction and contest: users are interacting and competing among themselves and obstacles.

\section{Serbia Convention Bureau: Profile and background}

Serbia Convention Bureau (SCB) was established in May 2007 as one of the departments within the National Tourism Organization of Serbia (NTOS). The initiative for establishment came from the private side, and was led by major congress hotels and agencies. At the moment, SCB has two full-time employees. Mission of the SCB is to attract international meetings and events in order to create direct and indirect effects for partners, stakeholders, and country as a whole [18].

In 2007, the year of SCB's establishment, Serbia was ranked as $64^{\text {th }}$ on the global ranking of destinations attracting international association meetings, while Belgrade was in the $168^{\text {th }}$ position in the world and $92^{\text {nd }}$ in Europe. Six years after, Serbia joined the top 50 international destinations and Belgrade moved to $55^{\text {th }}$ position, making Serbia one of the fastest growing destinations [9, pp. 3-7].

This progress is based on the well-established relationship within the meetings industry providers in the country. Relations with the meetings industry in Serbia are based on the Partnership Program, which was launched in 2008, with the aim to gather representatives from all MICE segments in order to unify efforts in developing and marketing Serbia for the international MICE clients. Due to a lack of private-public partnership legal frames, the Partnership Program allowed SCB to act as an industrydriven destination management organization. One of the basic principles of the Partnership is the golden rule, according to which SCB treats all Partners equally and shares all information among them [17].

The financial sustainability of SCB activities is also pertinent to this case study. SCB is financed by the government, but through NTOS's annual program, and the average annual budget of SCB is approximately one hundred thousand Euros. A detailed analysis of the activities shows that $70 \%$ of the SCB budget is taken up by the participation costs at two major travel shows IMEX (Frankfurt, Germany) and EIBTM (Barcelona, Spain), and those include costs of stand space and construction, travel and accommodation costs, and the production of collateral material. The remaining $30 \%$ of the budget is used to cover activities like FAM trip organization, site inspections, destination presentations, international cooperation with recognized associations, convention bidding, and cooperation with media [9].

Therefore, it is important to emphasize that these very limited resources, both financial and human, need to be used strategically, and especially on things that will create synergetic benefits and return on investment, as well as activities that will facilitate the process of positioning of Serbia as a meeting destination on an already highly competitive market.

\section{Destination marketing management application in practice: Serbia Convention Bureau case study}

Following the major marketing trends and developments in the Serbian ICT sector, SCB decided to go step forward in destination management and client relationship management. Idea was to provide unexpected tool for business travel demand, especially for meeting and incentive planners, a tool that would enhance Serbia position as a meeting destination and that would be based on the gamification principles for the first time applied in the meetings industry. 
SCB developed two video games with the specific aim of making the relationship with clients and potential clients more interactive and engaging them in a twoway communication. Another important point in favor of video games is the fact that they make it possible for SCB to engage with the direct consumers of the meeting and incentive products in Serbia, namely the event participants. The first of these games is more focused on the incentive products in Serbia and targets incentive planners as well as general tourists. The second video game targets meeting planners. These games can be said to be successful due to various factors. Firstly, they are certainly the very first video games that are focusing mostly on the meetings industry stakeholders. SCB discovered through its own benchmarking research that there were indeed some destination games but their content related purely to leisure tourism. So these games would make SCB a true pioneer in applying new marketing trends within the meetings industry. Secondly, the games make clients aware of the varying possibilities in Serbia in a completely different, game-related way. Basically, the clients have fun playing the game, but at the same time they learn about Serbia as a meeting and incentive destination. Also, the concept of gamification, as discussed in the literature review, is aimed at facilitating better relations between SCB and its existing and potential clients, especially the new generations of managers (so-called Generation $\mathrm{Y}$ or Millennials). Lastly, of course, the games provide a new platform for the promotion of the SCB Partners.

The first video game "Tour de Serbia" is focusing on the incentive products in Serbia. The idea of the game is to race different tracks in the five selected destinations in Serbia that offer the experience and quality to attract international groups. Players/clients are racing against time and obstacles, but at the same time the track is passing major attractions and highlights of a destination. In addition, the vehicle that the player/client can choose for racing in a destination actually matches the complete theme and message of a destination and that is also clearly understandable from the selected highlights and attractions. For example: Belgrade, as the capital of Serbia, is an urban city renowned for its variety of nightlife and therefore the player will race in a sports car, while on the other hand if someone chooses Kopaonik, the major ski resort, he/ she will have the opportunity to race in a snowmobile. At the same time destination highlights and attractions that line the path of the race engage the player/client in the type of experience that they can achieve and expect in that particular destination.

The second video game "Make an Event in Serbia" is focused on the meeting, congress and events products in Serbia. The game offers the possibility for the player/client to engage in five selected destinations in Serbia. As was the case in the first game, these destinations were selected on the basis that they provide the experience and quality to host international events in Serbia. Depending on a destination and its capacities, the tasks also vary, from organizing small corporate meetings in the mountain resort to handling big association congresses in the capital city. So, each destination offers a different task of organizing an event within a given budget and using real service providers in that destination, bearing in mind that all given prices (although given in imaginary currency) are based on their real level of service and correct price/ quality ratio. In addition, the game features all major service providers in a destination (congress centers, hotels, unusual venues, restaurants) and each presented entity has a profile, which is composed of a brief, meetings-oriented description, several pictures and terms (prices) of use. The game is successfully completed if one passes four major steps. The first step is to choose an event venue. Depending on the size, purpose, price and location of an event, the player can choose a certain venue. The second step is to determine the official hotels for the event. The system is shuffling the room blocks a hotel can provide you, so every time you play the game, you will need to choose another option. In the third step, the player needs to decide on a gala dinner option, while in the fourth step he or she can choose pre and post excursion options. These steps are defined based on market research and SCB's experience with international clients, since they are matching the most common forms of meetings.

To populate the game experience it was important that all companies and service providers that signed the SCB Partnership Program had an equal opportunity of being showcased in the videogames. In addition, in order to 
make games more attractive and to put more emphasis on the experience within listed destinations, key attractions are also being presented (from city highlights to natural attractions). Partner material was customized from the SCB database in order to fit different communication channels (pictures, texts, contacts).

Creating the first destination video games aimed at the meetings industry clearly gave $\mathrm{SCB}$ a good theme for additional country awareness promotion. SCB launched the games during the IMEX Trade Fair in 2012. Demand stakeholders (hosted buyers, corporations, associations, media) had the opportunity both to demonstrate games and be a part of the experience, as well as to comment, suggest and criticize, so the SCB could implement those.

Techniques that the SCB games are using in the process of attracting and retaining client are:

- Reduction: Tour de Serbia complexity is on the low level, and there are no significant problems in reaching finish; it is similar with Make an Event in Serbia, where tasks and budget boundaries are automatically changed with every new log on.

- Tunneling: this technique is most visible within Make an Event in Serbia, where user is passing four, chronologically defined stages.

- Tailoring: introduction texts, Partner profiles, clearly defined steps and levels provide easy information display and search.

- Suggestion: this technique is not present in an explicit manner.

- Self-monitoring: feedback is provided through the notifications when the rules are broken.

- Conditioning: virtual ranking system and the real award system increase client retention and satisfaction.

Table 1: Goals and outcomes of SCB gamification

Goal
To develop and implement gamification project (two video games)
within given budget

To be present in all major free social media and other internet sites in the period of six months after the project initiation

To surprise and excite clients about doing business with Serbia by using gamification principles, an innovative marketing tool

To use innovative communication channels for the purpose of presentations, promotions and selling meeting capacities of SCB Partners

To increase awareness in domestic press and trade media of Serbia; no budget planned for this activity

To increase awareness in international press and trade media; no budget planned for this activity

To get international attention and to increase the meetings industry recognition; no budget planned for this activity

To reach 1,000 users (potential clients) for both games in the first six months and 1,800 in the first twelve months; no budget planned for this activity

To use gamification as a basis for positioning Serbia as a destination for green meetings

To create positive image

\section{Outcome}

Project realized within given budget; project has followed the financial limitations, including the cost of initial market launch during the IMEX2012 and further customizations based on the client feedback from IMEX

Developed games were available on the SCB website, SCB Facebook page, as application on Facebook, and on over 100 free online game portals within six months after the project initiation

Reactions to live presentations showed a high level of interest and satisfaction

Limitations of set goal is that the outcome could only be followed up during the face-to-face presentation and direct conversations during the IMEX

All SCB Partners are present within games and they have possibility to use these channels to promote and sell their products

A total of 14 free articles about SCB and its effort to implement gamification; total value of published articles is twice as much as the budget invested in gamification

A total of 32 free articles about SCB and its effort to implement gamification; total value of published articles exceeds the initial development budget four times

Over 14 industry presentations and participations in panel sessions in sixmonth period during the international meetings industry related events

1,129 users played the games in the first six months, and 1,812 in the first twelve months

By investing in creating digital channels the budget for printed and other traditional materials is significantly reduced

Feedback from the clients and stakeholders showed better perception and understanding of Serbia as a meeting destination 


\section{Results}

SCB set the goals that were to be achieved by using gamification (see Table 1). Some of the goals are too generic and their fulfillment is not solely based on gamification, but on integrated marketing activities as well. At the same time, it is hard to define direct effects, since most of the SCB activities are marketing-oriented.

\section{Conclusion}

The gamification concept, although originated from the digital media industry, has found the application in the field of business management, including destination management and destination marketing. Only a limited number of authors researched this highly interesting subject, but with no relation to destination management. Therefore, the paper suggests a variety of existing definitions and concepts, and defines gamification as a tool for developing relationship with potential clients and retaining existing clients by using non-typical and dynamical game environment in communicating destination experiences. The essence is to set gamification as a marketing tool for increasing clients' awareness about destinations and to communicate indirectly destination added values, which indirectly implies that the destination sales are done "in between the lines" after being first communicated via the game elements and game design. The case study demonstrates that gamification found its application in destination management. Results show that gamification ROI is positive and multiple. Above all, free promotional texts in media generated multiple returns. In addition, positive destination image has been created in the minds of potential international clients. It is important to note that it is not possible to confirm the gamification effect on lead generation and increase in destination sales.

\section{References}

1. 900 ctane (2012, September 7). Game on with B2B gamification [Blog post]. Retrieved from http://blog.90octane.com/09072012/ game-on-with-b2b-gamification/

2. Antin, J., \& Churchill, E. (2011, May). Badges in social media: A social psychological perspective. In CHI 2011 Gamification Workshop Proceedings (pp. 1-4).Vancouver, BC, Canada.
3. Buhalis, D. (2013, September). eTourism futures: Content, context, co-creation and other eTourism predictions for the next 20 years. Paper presented at Resort Development Organisation RDO Conference 2013. Gran Canaria, Spain.

4. Burke, M., \& Hiltbrand, T. (2011). How gamification will change business intelligence. Business Intelligence Journal, 16(2), 8-16.

5. Crumlish, C., \& Malone, E. (2009). Designing social interfaces: Principles, patterns, and practices for improving the user experience. Sebastopol, USA: O'Reilly Media.

6. Deterding, S., Khalded, R., Nacke, L., \& Dixon, D. (2011, May). Gamification: Toward a definition. In CHI 2011 Gamification Workshop Proceedings. Vancouver, BC, Canada. ACM 978-14503-0268-5/11/05

7. Eickhoff, C., Harris, C. G., Arjen, P., de Vries, A., \& Srinivasan, P. (2012). Quality through flow and immersion: Gamifying Crowdsourced Relevance. In Proceedings of the 35th International ACM SIGIR Conference on Research and Development in Information Retrieval. Portland, Oregon, USA

8. Gartner. (2011, November 9). Gartner predicts over 70 percent of global 2000 organisations will have at least one gamified application by 2014 [Press release]. Retrieved from http:// www.gartner.com/newsroom/id/1844115

9. International Congress and Convention Association. (2013). ICCA statistics report 2012. Amsterdam: ICCA.

10. Juul, J. (2005). Half-real: Video games between real rules and fictional worlds. Cambridge, MA: MIT Press.

11. Kleinberg, A. (2011, July 18). How to gamify your marketing [Blog post]. Retrieved from http://mashable.com/2011/07/18/ gamification-marketing/

12. Kroeze, C., \& Olivier, M. (2012, August). Gamifying authentication. In Proceedings of Information Security for South Africa Conference ISSA 2012 (pp. 56-63). Johannesburg, South Africa.

13. Llagostera, E. (2012). On gamification and persuasion. In SB Games 2012 Proceedings. Brazilian Symposium on Computer Games and Digital Entertainment 2012. Brasilia.

14. Palmer, D., Luncefor, S., \& Patton, A. (2012). The engagement economy: How gamification is reshaping businesses. Deloitte Review, 11, 53-69.

15. Salen, K., \& Zimmerman, E. (2012). Rules of play: Game design fundamentals. Cambridge, USA: MIT Press.

16. Serbia Convention Bureau (2008). Partnership Program 2008. Belgrade: SCB.

17. Serbia Convention Bureau (2013). Annual activity report 2012. Belgrade: SCB.

18. Serbia Convention Bureau [web site database]. Retrieved from http://m.scb.travel/

19. Wegert, T. (2012, November 29). Your 2013 marketing goal - Gamification [Blog post]. Retrieved from http://www.clickz. com/clickz/column/2228218/your-2013-marketing-goalgamification

20. Wolfe, D., \& Mott, A. (2012, August). B2B Gamification: How autodesk used game mechanics for in-trial marketing [PowerPoint presentation]. Presented at Marketing Sherpa B2B Summit 2012: Capture. Nurture. Convert. Orlando.

21. World Travel Market Trends (2011, November). WTM global trends report. London: WTM in association with Euromonitor International. 

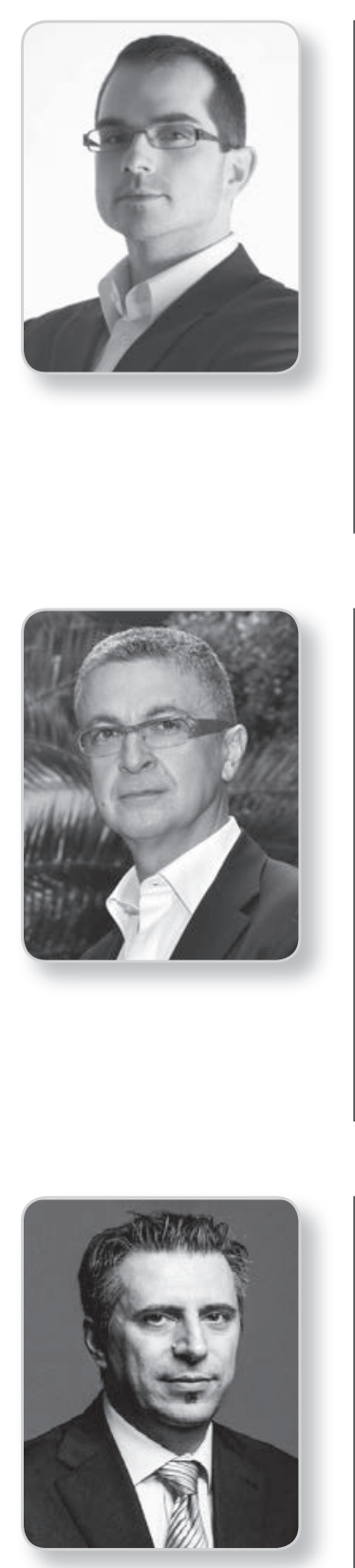

\section{Igor Kovačević}

is a Teaching Assistant at the Faculty of Economics, University of Belgrade. He lectures in the area of business economy and management (Marketing in Tourism, Management of Tourism Enterprises) and in the area of economic policy and development (Tourism Economics). Currently, he is a doctoral student in the field of destination management and marketing. Academic and professional interests are focused on tourism marketing and management, with special emphasize on the meetings industry (MICE) and business travel.

\section{Bojan Zečević}

is an Associate Professor at the Faculty of Economics, University of Belgrade. He received professional and advanced training from some of the major universities in Europe and USA in the field of tourism and especially of modern tourism management. At the bachelor's level of studies, his teaching commitments cover the courses of Tourism Economics and Marketing in Tourism. As for the master's studies, he has developed and runs Tourism Management Module, and he also lectures Strategic Management of Tourism Enterprises and Strategic Management of Tourism Destinations. He is an active member of scientific and professional organizations from the field of tourism abroad and in the country. Besides significant enrolment in the educational and teaching aspects, he is also a regular member of numerous scientific and research NICEF projects, various ministries and public institutions projects, as well as a recognized business consultant.

\section{Saša Veljković}

is an Associate Professor and Head of the Center for Continuing Professional Development at the Faculty of Economics, University of Belgrade. At the bachelor's level of studies, his teaching commitments cover the courses of Marketing and Services Marketing, while at master's studies he teaches Brand Management and Direct Marketing, as well as Business Skills in the joint program of Faculty of Economics and HEC (Paris), and Marketing $1 \mathrm{D}$ on PhD studies at the Faculty of Economics. He gained significant practical experience within organizations and companies from various fields. He managed and participated in over 40 projects in the field of marketing, services marketing, market research, brand management, strategic marketing etc. He is an active member of business and academic organizations, and Secretary General of the Serbian Marketing Association. 